OPEN OACCESS
Cross-cultural Management / Zarządzanie międzykulturowe

Michał Tuszyński

ORCID: 0000-0002-5424-2713

SGH Warsaw School of Economics

michalpoczta@onet.com.pl

DOI: 10.35765/pk.2019.2502.07

\title{
Macro-prudential Policy \\ and its Impact on the Reduction \\ of Systemic Risk
}

ABSTRACT

The main objective of this paper is a holistic representation of the idea of macro-supervision, pointing to the need for its implementation and demonstration based on research and historical data that macro-prudential policy can significantly prevent the materialization of systemic risk in the banking business. This means that it will be able to counteract this risk in both temporal and structural terms, translating into better functioning of the real economy, which the financial system primarily serves. The article will present the history of the idea of macrosupervision and its concept in the light of different economic schools. Next, the characteristics of the financial system, sources of systemic risk and macro-prudential policy objectives will be shown. Attention will also be given to the other objectives of this idea. In the next stage of work, a range of policy instruments will be presented.

KEY WORDS: European Union, financial system, macroprudential supervision 
STRESZCZENIE

Polityka makroostrożnościowa i jej wptyw na zmniejszanie ryzyka systemowego

Głównym celem artykułu jest holistyczne przedstawienie idei makronadzoru, wskazanie na potrzeby jej implementacji oraz wykazanie na podstawie danych historycznych i badań, że polityka makroostrożnościowa może istotnie przeciwdziałać materializacji ryzyka systemowego w działalności bankowej. Oznacza to, że będzie ona w stanie przeciwdziałać temu ryzyku w wymiarze zarówno czasowym, jak i strukturalnym, przekładając się na lepsze funkcjonowanie gospodarki realnej, której system finansowy przede wszystkim służy. W pracy została przedstawiona historia idei makronadzoru oraz opisana charakterystyka systemu finansowego, źródła ryzyka systemowego, a także cele i instrumenty polityki makroostrożnościowej.

SŁOWA KLUCZE: Unia Europejska, system finansowy, nadzór makroostożnościowy

\section{Introduction}

Macro-supervision is a concept that assumes to become an important binder between micro-prudential and macroeconomic policies. As an idea, its main objective is to maintain the stability of the financial system, and as a policy it will use both its own instruments and the already existing ones. Together with existing prudential policies, macro-supervision has the opportunity to create a robust system to monitor the activities of economic system operators, with particular attention also being paid to the links between the relevant operators within this system.

This is an extremely important topic from the point of view of the financial system, which is nowadays highly correlated with the real economy, and its instability can be a major threat to the development of economies in terms of individual countries, organizations of several countries with varying degrees of integration, or global development. Appropriate measures to preserve such macro-stability of the financial system may be necessary nowadays.

The paper will verify the hypothesis that a properly introduced macro-prudential policy can effectively reduce the probability of materializing systemic risk, as historically introduced in individual countries, it has 
already provided tangible benefits in terms of maintaining macro-stability of the financial system.

\section{History and characteristics of macro-supervision}

In general, the objective of a macro-prudential policy is to manage factors that may jeopardize the stability of the financial system as a whole, even if these factors do not appear to be dangerous when viewed from the perspective of individual activity.

In the financial system, the following risks can be distinguished: ${ }^{1}$ liquidity risk; counterparty risk; market risk; credit risk; interest rate risk; currency risk; operational risk; strategic risk; and systemic risk. Naturally, any sharing of risks is quite arbitrary and seems to escape the standard framework within which it could be exactly closed, so defining risk is quite ambiguous. Nevertheless, the above segmentation provides an opportunity to take a closer look at the risks in the financial system.

The concept of macro-supervision, which refers to keeping structural (systemic) risks in check, is aimed at threats that are always present in the economy to some extent, while the concept of cyclical risk draws attention to the catastrophic banking activity, which intensifies both a bull (overheating of the economy) and bear market (deepening of recession). Macro-prudential policy, in its applied nature, is a policy of relatively short duration, however, even as an idea it appeared much earlier than the date of the collapse of the US mortgage market would indicate.

Currently, the main functions of the entire banking system are considered to be mainly:

- creating mechanisms for gathering funds and investing them in various undertakings,

- providing effective banking risk management solutions,

- providing price information

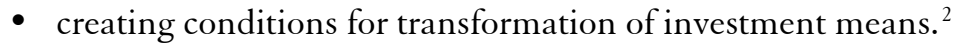

These points are the core of the banking system. Generally speaking, the more effectively they are filled by the banking sector, the more stable the sector operates, and vice versa, the further away the system goes away from these guidelines for various reasons, the more fluctuations it is exposed to. The main task of macro-prudential policy is therefore to influence the banking sector (or, more broadly, the financial sector) in such

1 M. Iwonicz-Drozdowska, Bankowośc zagadnienia podstawowe, Poltext, Warszawa 2010, p. 231.

2 W. Jaworski, Wspótczesny bank, 2nd ed., Poltext, Warszawa 2000. 
a way as to prevent significant deviations from this set of rules even in the preventive phase.

Interestingly, depending on the approach, the role of the financial system in the transmission of crises has been differently emphasized. British economist and representative of the post-Keynes school, Joan Robinson, said in one of her works ${ }^{3}$ that the development of this sector follows more directly with the development of the whole country, rather than develop independently of it. In a similar vein also spoke Nobel Prize winner, American economist Robert Lucas. ${ }^{4}$ He considered excessive concern about the role of the financial sector (in the transmission of crises) to be unnecessary. Today it is known that both Robinson and Lucas did not formulate their ideas entirely accurately.

One of the first scientists to draw attention to the important role of feedback between the financial system and the real economy was an American economist, Irving Fisher. Just as the real beginning of the implementation of the macro-supervision policy was the outbreak of the crisis of 2007, so the beginning of the idea itself was the crisis of 1929. Four years after the beginning of the greatest downfall of the 20th century, Fisher presented his concept of debt deflation, ${ }^{5}$ which can be presented as a cause and effect chain in 9 steps:

1. The necessity of debt liquidation leads to a sudden and frantic fire sell of assets. ${ }^{6}$

2. Shrinkage of deposits with the repayment of bank loans and slowing down the pace of money circulation

3. Decreasing aggregated deposits and reduced speed of money circulation due to sudden asset sales

4. A fall in the general price level, which (if undisturbed by deflation) contributes to a further decline in the net worth of businesses and an increased number of bankruptcies

5. Decrease in corporate profits

6. Social anxiety about the future of companies whose profit dynamics are significantly decreasing which results in a reduction in overall production, a decrease in the value of trade and an increase in unemployment

7. Increased overall pessimism and decreased investor confidence

3 J. Robinson, The Rate of Interest and Other Essays, Macmillan, London 1952.

4 R. Lucas, On the Mechanics of Economic Development, "Journal of Monetary Economics," 1998, No. 1.

5 I. Fisher, The Debt-Deflation Theory of Great Depressions, "Econometrica," 1933, No. 4, p. 342.

6 Fisher here uses the term distress selling, currently used, however, the term fire sells, meaning a sudden sale of assets will be used herein. 
8. Hoarding money and slowing down its circulation

9. Nominal declines and increases in real interest rates, due to deflation.

Although the 20th century economy was much more affected by inflation than by deflation, this does not mean that Fisher's pattern is not correct. In fact, less than 80 years later, the pattern repeated itself, and a fire sale which initiates the pattern, occurred again. In this sense, the banking sector, through its pro-cyclical activities, contributed to the exacerbation of the crisis, causing a significant drop in property prices through massive property sales.

One of the numerous effects of the financial crisis was the development of a set of recommended market practices for financial risk management in the financial sector. The Basel Committee on Banking Supervision was established at the end of 1974 at the Bank for International Settlements in Basel, created by central bank directors belonging to the G10. Its first meeting was held in February $1975 .{ }^{7}$ The Committee's intention was to provide a platform for regular cooperation on the broader issue of supervision of the financial system, with the aim of highlighting the role of monitoring the activities of financial actors in maintaining the stability of the sector. ${ }^{8}$

Members of the Committee are currently CEOs of monetary policy institutions, in 60 different countries, mainly from the EU, North America and Asia (but also from South America and Africa). The most important documents issued by the Basel Committee are the 1988 Capital Accord (UK) (colloquially called Basel I), the 2004 New Capital Accord (NUK) (colloquially called Basel II) and the latest agreement known as Basel III, of 2010.

The arrangements of the Basel Committee under the III Capital Agreement are the crowning achievement of the development of the macro supervision concept. In Poland, this concept is materialized under the "Act on macro-prudential supervision of the financial system and crisis management in the financial system" of 15 August 2015. It provides a framework for the implementation of this policy in the Republic of Poland.

\section{Systemic risk characteristics and place of macro supervision in the financial system}

Given the specific risks that may arise in the financial system, there is a need to manage these risks properly and to prevent them from escalating.

7 Basel Committee on Banking Supervision chronology, http://www.bis.org/about/chronology. htm? $\mathrm{m}=1 \% 7 \mathrm{C} 4 \% 7 \mathrm{C} 550$ (access: 09.12.2018).

8 Basel Committee on Banking Supervision, http://www.bis.org/bcbs/index.htm (access: 09.12.2018). 
The set of rules and principles that relate to preventive actions before systemic risk materializes is called macro-prudential policy.

Macro-supervision policy is explained comprehensively by Claudio Borio, ${ }^{9}$ juxtaposing its direct and indirect targets with micro-prudential policy objectives. An additional comparison is made between the risks these policies manage and how their instruments are calibrated. The comparison is shown in Table 1.

Table 1. Comparison of macro- and micro-prudential policies

\begin{tabular}{|l|l|l|}
\hline Categories & Macro-supervision & Micro-supervision \\
\hline Indirect objective & $\begin{array}{l}\text { Limiting risk across the } \\
\text { financial system }\end{array}$ & $\begin{array}{l}\text { Limiting the risk of the } \\
\text { individual units in the } \\
\text { financial system }\end{array}$ \\
\hline Direct objective & $\begin{array}{l}\text { Avoiding recession as } \\
\text { measured by a fall in real } \\
\text { GDP }\end{array}$ & $\begin{array}{l}\text { Protection of the client/ } \\
\text { bank's depositary }\end{array}$ \\
\hline Risk model & Partly endogenous & Exogenous \\
\hline $\begin{array}{l}\text { Correlation and common } \\
\text { institutions }\end{array}$ & Significant & Non-significant \\
\hline Calibration of instruments & $\begin{array}{l}\text { In the sense of influencing } \\
\text { the system as an integral } \\
\text { whole, "top down" }\end{array}$ & $\begin{array}{l}\text { In the sense of individual } \\
\text { entities in the system, } \\
\text { "bottom up" }\end{array}$ \\
\hline
\end{tabular}

Source: C. Borio, Towards a macro-prudential framework for financial supervision and regulation? BIS, Iss. 128, 2003, p. 2, http://www.bis.org/publ/work128.pdf (access: 09.12.2018).

Borio points to three main elements in favor of the implementation of macro-prudential policy: ${ }^{10}$

1. high costs of materializing systemic risk for the whole economy,

2. the need to maintain a balance between state surveillance and market self-regulation,

3. the nature of financial instability and its sources.

In this dimension, macro-supervision also becomes responsible for the proper functioning of non-financial sectors, i.e. not allowing too much fluctuation of real GDP in relation to potential, both upward (overdraft) and downward (sub-optimal flow of credit to the economy).

A special type of risk, which is systemic risk, is worth our attention for at least two reasons. Firstly, it tends to accumulate in good times, when

9 Claudio Borio is a doctor of economics at Oxford University; since November 2013 he is President of the financial and economic department at the Bank for International Settlements.

10 C. Borio, Towards a macro-prudential framework for financial supervision and regulation?, "BIS," 2003, Iss. 128, p. 2, http://www.bis.org/publ/work128.pdf (access: 09.12.2018). 
the tendency to estimate it is significantly lower, and secondly, it may lead to the collapse of the entire financial system, even if the particular actors of a market act in accordance with a policy of correct and fully logical risk management from a micro perspective. The systemic risk sharing proposed by the International Monetary Fund is presented in Table 2.

Table 2. The dimensions of systemic risk, according to the IMF

\begin{tabular}{|c|c|}
\hline Time dimension & Cross-sectional dimension \\
\hline $\begin{array}{l}\text { The mechanism is based on the belief } \\
\text { that in good and bad times, the risk } \\
\text { estimated by financial market agents and } \\
\text { other markets is underestimated and } \\
\text { overestimated, respectively. What in the } \\
\text { former case aggravates the process of risk } \\
\text { accumulation, in the latter case makes it } \\
\text { difficult to recover from recession caused } \\
\text { by the materialization of that risk. }\end{array}$ & $\begin{array}{l}\text { It refers to the risk already accumulated } \\
\text { at the moment. If the mechanism of risk } \\
\text { accumulation over time as a result of pro- } \\
\text { cyclical activity of the financial system } \\
\text { is dynamic and is a process, then the } \\
\text { occurring risk in the structural dimension } \\
\text { may additionally drive the materialization } \\
\text { of systemic risk, with its simultaneous } \\
\text { occurrence of risk in the temporal } \\
\text { dimension. }\end{array}$ \\
\hline $\begin{array}{l}\text { Pro-cyclicality in the financial system is } \\
\text { most often an expression of the volatility } \\
\text { in the size of banks' aggregate lending } \\
\text { and changes in their overall liquidity } \\
\text { levels caused by their excessive leverage } \\
\text { and maturity mismatches in their balance } \\
\text { sheets. }\end{array}$ & $\begin{array}{l}\text { In certain situations, however, the } \\
\text { structural dimension of risk may also } \\
\text { exist in isolation from the temporal } \\
\text { dimension. Such situations may certainly } \\
\text { include exposures of financial sector } \\
\text { entities to the same assets, or very close } \\
\text { interconnectedness; if, in addition, there } \\
\text { is a single parent entity in such a financial } \\
\text { system that is systemically important for } \\
\text { the sector as a whole, the so-called SIFI, } \\
\text { its failure, or even liquidity problems, } \\
\text { may affect other entities in the network. } \\
\text { Otherwise, materializing risk in this very } \\
\text { large entity may be risky not only for the } \\
\text { entity itself, but also for other institutions } \\
\text { in this sector, through transmissions of } \\
\text { this materialized risk, through contagion } \\
\text { effect channels. }\end{array}$ \\
\hline
\end{tabular}

Source: the author's own development based on: Macroprudential Policy - An Organizing Framework, International Monetary Fund, 2011. 


\section{Macro-prudential policy instruments}

Macro-prudential policy instruments may be adapted to the appropriate risks. The most important risks in the financial system are liquidity and credit risk. Liquidity risk is the likelihood of a change in the desired degree of liquidity held by a financial institution. The state in which liquidity is too low may occur in some cases. As a result of changes in interest rates or sudden withdrawals of deposits by customers during panic (so-called run on banks), the value of such deposits may decrease dramatically, causing short-term or long-term liquidity problems. Additional risk factors may also include an increase in the number of deposits withdrawn before maturity, unforeseen costs of banking activities (e.g. related to the introduction of a banking tax) or, above all, a change in customers' risk preferences.

The instruments that can limit the probability of materialization of liquidity risk include, first of all:

- LCR (liquidity coverage ratio) indicators,

- NSFR (net stable funding ratio) indicators,

- liquidity buffers,

- mandatory reserve rate.

LCR and the NSFR indicators provide a measure of operating liquidity, recommended for implementing by the Basel Committee on Banking Supervision (Basel III). The main aim of the $\mathrm{LCR}^{11}$ is to promote the materialization of banks' resilience to short-term liquidity risk. The bank must therefore have an adequate stock of unencumbered, liquid, highquality assets (HQLAs) which can be instantly transformed into cash, and which should provide 30-day operations of the bank, as part of the fulfillment of the liquidity shortage scenario. The greater the liquidity of the assets, the greater weight suited to them.

LCR is calculated as the quotient of high-quality assets (HQLA) by Net Cash Outflows over a 30-day time period (NCO).

$$
\mathrm{LCR}=\frac{\mathrm{AQLA}}{\mathrm{NCO}}
$$

If the liability item within the NCO is very stable, its weight is quite small (to a lesser extent the liability is to be covered by liquid funds from the HQLA inventory). ${ }^{12}$ According to the Basel Committee, the proper

11 "Basel III: The Liquidity Coverage Ratio and liquidity risk monitoring tools," Bank for International Settlements, 2013, p. 7, http://www.bis.org/publ/bcbs238.pdf (access: 21.03.2016).

12 P. Niedziółka, Analiza potencjalnych korzyści oraz negatywnych konsekwencji wdrożenia norm LCR oraz NSRF w bankach europejskich, SGH, p. 2, http://kolegia.sgh.waw.pl/pl/KES/kwartalnik/Documents/PN231.pdf (access: 21.03.2016). 
functioning of the LCR measure aims to improve the banking sector's ability to absorb economic and financial shocks, regardless of their source, as well as reduce the incidence of adverse spillover effects that could adversely affect the entire economy. The standard promoting financial stability in the sense of liquidity has also been extended by the Committee to include longer-term liquidity requirements.

A complementary measure of the LCR is therefore the NSFR, which is to provide liquidity to banks for up to 1 year (365 days). Its main task for institutions is to go from unstable long-term projects financing (e.g. to grant mortgage loans) with short-term resources (e.g. short-term deposits). This phenomenon, commonly known as the maturity mismatch between assets and liabilities, can pose a serious risk of creating negative externalities for the system as a whole if financial institutions were suddenly forced to sell off assets as liquidity buffers. Financing banks from short-term roll-over deposits on the interbank market is to replace the acquisition of funds from medium and long-term deposits and/or long-term debt securities.

$\mathrm{NSFR}^{13}$ is calculated by dividing the available amounts of AASF (Amount of Available Stable Funding) and the sum of RASF (Required Amount of Stable Funding).

$$
\mathrm{NSFR}=\frac{\mathrm{AASF}}{\mathrm{RASF}}
$$

Similarly, to the LCR, the more stable the type of financing (AASF), the higher its weight. Since RASF is the sum of weighted assets that need to be covered by liabilities of an appropriate quality, the more liquid these assets are, the lower their weight. ${ }^{14}$

The most characteristic type of risk to be managed by a bank is credit risk, understood as the possibility of deterioration of the situation of a financial entity with which we have a contract.

Expansionary credit action can fuel the creation of a speculative bubble and thus lead to an increase in the value of assets. If the revaluation of these assets is precisely due to the easy availability of credit, the use of the macro-prudential policy instrument known as the LTV (Loan-To-Value) ${ }^{15}$ indicator may be a good solution.

13 "Basel III: the net stable funding ratio", Bank for International Settlements, 2014, http://www. bis.org/bcbs/publ/d295.pdf (access: 21.03.2016).

14 P. Niedziółka, Analiza potencjalnych korzyści oraz negatywnych konsekwencji wdrożenia norm LCR oraz NSRF $w$ bankach europejskich, SGH, p. 5, http://kolegia.sgh.waw.pl/pl/KES/kwartalnik/Documents/PN231.pdf (access: 01.02.2018).

15 If, for example, the value of a property is $1,000,000 \mathrm{PLN}$, and the mortgage granted for it is $800,000 \mathrm{PLN}$, the LTV ratio $=800,000 \mathrm{PLN} / 1,000,000 \mathrm{PLN}=80 \%$. The lower the LTV, the greater the down payment required from the borrower. 


$$
\text { LTV }=\frac{\text { Lending value }}{\text { Value of collateral }}
$$

Research ${ }^{16}$ shows that adequate regulation of LTV may have a significant impact on changes in real estate prices. The correlation between this measure and real estate prices is positive (an increase in LTV by 10 percentage points is accompanied by an increase in nominal real estate prices by approx. 13\%) this indicator should be variable over time, higher in the time of a downward trend and lower in the time of a boom. It is complementary to another indicator that could affect the size of aggregate lending, known as DTI (Debt-To-Income).

$$
\mathrm{LTV}=\frac{\text { Loan service charge }}{\text { Income }}
$$

DTI is a measure of how much the lending institution burdens the debtor with the loan and the need to service its interest. Most often, therefore, the meter is the sum of the installment and the interest on the loan in a given period, compared to the amount of the debtor's income in the corresponding period. It is worth noting that we are talking about net income (after tax), however, the measure of such income may also be the amount of money that the borrower will have at his disposal after deducting not only tax but also some other fixed payments such as repayment of other loans, or the need to pay other than income taxes (e.g. on real estate). It is worth noting that the DTI that is constant in time can have a pro-cyclical effect, ${ }^{17}$ just as the LTV should be variable in time, and just as it should be higher in time of downhill and lower in time of boom.

It is estimated ${ }^{18}$ that prudent lending practices in Hong Kong resulting, among other things, from the introduction of LTV and DTI limits as complementary macro-prudential policy instruments, stopped the 1994 real estate boom, protecting Hong Kong from the 1997 crisis. For example, the LTV index was also reduced in China after the 2008 crisis - in 2010-2011 from $80 \%$ to $70 \%$ for the purchase of the first home and to $50 \%$ (in 2010) and then $40 \%$ (in 2011) for the purchase of the second home. ${ }^{19}$

16 C. Crowe, G. Dell'Ariccia, D. Igan, P. Rabanal, Policies for macrofinancial stability: options to deal with real estate booms, International Monetary Fund, Staff Discussion Note, SDN/11/02, 2011, pp. 20-21.

17 Pro-cyclicality of constant DTI results, among others, from faster price growth than the income security.

18 C. Crowe, G. Dell'Ariccia, D .Igan, P. Rabanal, Policies for macrofinancial stability, op. cit., p. 21.

19 F. Columba, A. Costa, P. Kongsamut, C. Lim, A. Otani, M. Saiyid, T. Wezel, X. Wu, Macroprudential Policy: What Instruments and How to Use Them? Lessons from Country Experiences, MFW 2011, p. 74. 
The DTI ${ }^{20}$ was implemented in a large number of countries around the world. ${ }^{21}$ In South Korea it was introduced in 2005, and since then it has been counter-cyclically modified six times by October 2011 (reduced and doubled four times).

Among the tools for credit risk management, particular attention should also be paid to the possibility of reducing the amount of credit not only for the economy as a whole, but also for certain sectors of the economy that are suspected to have a speculative bubble. In this way, unlike interest rate regulation, the inflow of low-interest money is limited not to the whole economic system, but only to its elements, on which local bubbles caused by cheap credit may appear.

\section{Conclusions}

Macro-prudential policy is a relatively new concept for building a stable global financial system. Although the importance of financial institutions and markets was already recognized at the beginning of the 20th century, it was only in recent years that the possible negative impact of a collapse of the financial system on the whole economy was empirically confirmed. The idea that the stability of the system equals the stability of the individual entities that make it up was denied by the outbreak of the crisis. Macro-prudential policy can therefore be the answer to how to protect the financial system from its costly destabilization by becoming the link between micro-prudential policy and the economy of the whole country.

With a set of appropriately calibrated instruments, it can ensure that the functions carried out by the financial sector are not subject to shocks in view of the overall health of the economy. In addition, addressing these instruments to the relevant risks faced by the economy, i.e. differentiating between liquidity, counterparty, credit, interest rate, currency volatility, market fluctuations and ultimately general system risks, may allow the policy to operate more effectively and optimize its functions.

Examples confirming that macro-prudential policy can significantly counteract the materialization of systemic risk in banking operations include stopping the growing housing loan bubble in the mid-1990s, but also the use of unremunerated reserve requirements (URR), the mechanism of which acts as a tax without a fiscal function on capital inflows. An

20 Ibidem, pp. 74-80.

21 Among others, Colombia, Croatia, Greece, Hong Kong, Hungary, South Korea, Norway, Poland, Romania, Russia, Serbia and Thailand. 
URR of $20 \%$ was introduced, among others, in Chile 22 in June 1991. In August 1992, it was increased to 30\%. In June 1998, the URR was lowered to $10 \%$, and in September of that year it was abolished. As a result of the application of the URR from 1990 to 1997, short-term revenues (up to 1 year) as a percentage of total revenues decreased from $90.7 \%$ to $2.8 \%$, and long-term revenues increased from $9.7 \%$ to as much as $97.2 \%$.

An appropriate justification of the need to implement macro-prudential policy, its precise objectives, the identification and allocation of risks and appropriate instruments, and the creation of an appropriate functional and legal environment in which the policy can operate, can contribute to more stable global economic growth, by maintaining a balanced financial environment.

Despite the benefits that macro-prudential policy can bring when properly implemented, there is also a need to clearly identify the research gaps that would need to be filled by carrying out appropriate research, implicitly calibrated for the relevant economies which macro-prudential policy is to be applied to. The main question to be considered is whether one or more of these policy instruments should be introduced. The decision should in principle depend on what area of risk we address, but it should also be important in this case to examine whether the decision-making system should be automated or allow for more arbitrary decisions, and if so, to what extent? Furthermore, it would also be worth considering the stability of instruments over time, i.e. whether their range and calibration should change from period to period, and whether they should change in an anti- or pro-cyclical manner. Another important element is the impact of macro-prudential rules on fiscal, monetary and micro-prudential policies and on cross-border capital flows. It would be useful to examine which rules are complementary to each other and which are contradictory.

\section{BiBLIOGRAPHY}

Basel Committee on Banking Supervision, Bank for International Settlements, http://www.bis.org/bcbs/index.htm (access: 08.12.2018).

Basel Committee on Banking Supervision chronology, Bank for International Settlements, http://www.bis.org/about/chronology.htm? $\mathrm{m}=1 \% 7 \mathrm{C} 4 \% 7 \mathrm{C} 550$ (access: 08.12.2018).

22 T. Palley, Chilean Unremunerated Reserve Requirement Capital Controls as a Screening Mechanism, Washington DC, p. 12, http://www.thomaspalley.com/docs/articles/international_markets/chilean_reserve.pdf (access: 14.12.2019). 
Bernanke B., Gertler M., Gilchrist S., The Financial Accelerator in a Quantitative Business Cycle Framework, "NBER Working Paper," 1998, Iss. 6455.

Borio C., Towards a macro-prudential framework for financial supervision and regulation?, "BIS,” 2003, No. 128, p. 2, http://www.bis.org/publ/work128. pdf (access: 08.12.2018).

Burman L., Gale W., Gault S., Kim B., Nunns J., Rosenthal S., Financial transaction taxes in theory and practice, 2015, p. 10, http://www.brookings. $\mathrm{edu} /$ /media/research/files/papers/2015/07/financial-tax-transactions/financial-transaction-taxes.pdf (access: 08.12.2018).

Columba F., Costa A., Kongsamut P., Lim C., Otani A., Saiyid M., Wezel T., Wu X., Macroprudential Policy: What Instruments and How to Use Them? Lessons from Country Experiences, MFW, 2011.

Crowe C., Dell'Ariccia G., Igan D., Rabanal P., Policies for macrofinancial stability: options to deal with real estate booms, International Monetary Fund, Staff Discussion Note, SDN/11/02, 2011.

Fisher I., The Debt-Deflation Theory of Great Depressions, "Econometrica," 1933, Iss. 4.

Globalna architektura finansowa, European Central Bank, https://www.ecb. europa.eu/ecb/tasks/international/financialarchitecture/html/index. pl.html (access: 08.12.2018).

Iwonicz-Drozdowska M., Bankowość zagadnienia podstawowe, Poltext, Warszawa 2010.

Jaworski W., Wspótczesny bank, 2nd ed., Poltext, Warszawa, 2000.

Lucas R., On the Mechanics of Economic Development, "Journal of Monetary Economics," 1998.

Macroprudential Policy - An Organizing Framework, International Monetary Fund, 2011, https://www.imf.org/external/np/pp/eng/2011/031411.pdf (access: 09.12.2018).

Niedziółka P., Analiza potencjalnych korzyści oraz negatywnych konsekwencji wdrożenia norm LCR oraz NSRF $w$ bankach europejskich, SGH, http:// kolegia.sgh.waw.pl/pl/KES/kwartalnik/Documents/PN231.pdf (access: 01.02.2018).

Palley T., Chilean Unremunerated Reserve Requirement Capital Controls as a Screening Mechanism, Waszyngton, strona Thomasa Palleya, http://www. thomaspalley.com/docs/articles/international_markets/chilean_reserve. pdf (acess: 14.12.2019).

Robinson J., The Rate of Interest and Other Essays, Macmillan, London 1952.

Screening Mechanism, Washington DC, Thomas Palley's website, http://www. thomaspalley.com/docs/articles/international_markets/chilean_reserve. pdf (access: 08.12.2019).

Spicka P., Macroprudential oversight in Germany - overview, Deutsche Bundesbank 2015. 
The Act of 29 VIII 1997, Article 3 item 1, the Internet System of Legal Acts, http://isap.sejm.gov.pl/DetailsServlet?id=WDU19971400938 (access: 12.08.2018).

The Act of 5 August 2015, Macroprudential supervision.

Vulnerabilities Assessment, Financial Stability Board, http://www.fsb.org/what-we-do/vulnerabilities-assessment/ (access: 08.12.2018).

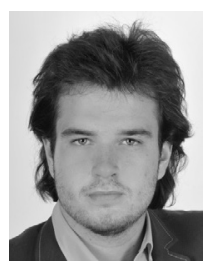

Michał Tuszyński - PhD student in Economics at the World Economy School at the SGH Warsaw School of Economics, where he also earned a Masters in Finance and Accounting with honors degree. Graduate of Economics at the Warsaw University of Life Sciences SGGW. Focuses on macroeconomics and finance in the broadest sense of the term, with particular emphasis on monetary policy, research into business and financial cycles, the derivatives market, as well as the analysis of the Austrian school, praxeology and finance, on top of behavioral economics. 